\title{
O PCC E A GESTÃO dOS PRESÍDIOS EM SÃO PAULO
}

ENTREVISTA COM NAGASHI FURUKAWA

\section{RESUMO}

Nesta entrevista, o ex-secretário de Segurança Pública do Estado de São Paulo Nagashi Furukawa faz um diagnóstico de sua gestão e dos impasses relacionados às políticas para a segurança pública no Brasil. A crise gerada pelos ataques do PCC (Primeiro Comando da Capital) em 2006, suas origens e conseqüências estão no cerne da conversa que se lê a seguir.

PALAVRAS-CHAVE: segurança pública; PCC; violência; sistema carcerário.

\section{ABSTRACT}

In this interview, former secretary of Public Security of the State of São Paulo Nagashi Furukawa discusses his administration and polices related to public security in Brazil. The crisis caused by the attacks of the PCC (Primeiro Comando da Capital) in 2006, its origins and consequences are among the main subjects of the interview.

KEYWORDS: public security; PCC; violence; carceral system.

Afastado do universo político desde o final de maio de 2006, quando deixou o comando da Secretaria da Administração Penitenciária (SAP) após a primeira onda de atentados do Primeiro Comando da Capital (PCC), Nagashi Furukawa rompe nesta entrevista um longo período de silêncio.

A megarrebelião de 2001, a ação do crime organizado no interior dos presídios e a crise de 2006 foram alguns tópicos da conversa. De maneira franca, o ex-secretário analisa as divergências políticas enfrentadas no interior do governo quando tentava superar a crise e elabora explicações possíveis para os ataques de maio de 2006. 
Além de exercer o cargo de secretário de estado entre 1999 e 2006 , Nagashi foi diretor do Departamento Penitenciário Nacional (DEPEN) e juiz por muitos anos em Bragança Paulista, o que o torna um dos maiores conhecedores da realidade carcerária do país. É a partir dessa longa experiência na área que ele comenta as políticas públicas atuais de enfrentamento da criminalidade e tece críticas às diversas instituições responsáveis pelo acompanhamento da execução penal no país. (Paula Miraglia e Fernando Salla)

Quando o sr. assumiu em 1999 a Secretaria de Administração Penitenciária de São Paulo, em que áreas o sr. encontrou mais dificuldades para trabalhar, tanto em relação aos presos como em relação aos funcionários e à administração?

Na época havia dificuldades de toda ordem, mas a maior delas, que me perseguiu durante os quase sete anos [1999-2006] que eu fiquei no governo de São Paulo, estava ligada ao aspecto material. É muito difícil desenvolver qualquer tipo de trabalho com eficiência quando não há espaço. Quando eu assumi a secretaria no final de 1999, havia noventa e poucas carceragens na capital, de 30 vagas cada, com 200 presos em média. Esse foi um desafio enorme. Além disso, havia a Casa de Detenção do Carandiru, com 3.300 vagas preenchidas por mais de 7 mil presos, recebendo mais 800 presos por mês. Mesmo que houvesse todos os recursos necessários para enfrentaressa situação, haveria outras dificuldades: a Lei de Licitação, encontrar local adequado para construir, o tempo necessário para a construção etc. Não era possível pensar em desenvolver um trabalho eficiente se não houvesse pelo menos uma vaga adequada para um preso. Nunca tivemos isso, apesar de serem inauguradas, nos seis anos e meio que estive na secretaria, 82 novas unidades prisionais - mais de uma por mês. Foi um trabalho enorme, mais de 60 mil vagas foram abertas nesse período, mas ainda assim insuficientes para fazer frente à quantidade de presos que o Estado de São Paulo tinha. Essa foi a maior dificuldade.

Outra dificuldade enorme foi a resistência dos diretores e funcionários mais antigos do sistema a qualquer tipo de mudança. Os procedimentos que eles aprenderam como forma correta de administrar uma penitenciária, de 40,50 anos atrás, eram os que vigoravam, eque, enfim, tenho que reconhecer, vigoram até hoje apesar das poucas mudanças que foram feitas e do enorme esforço para isso.

Por fim, a dificuldade em estabelecer um trabalho bem entrosado com a Secretaria de Segurança Pública foi outro grande problema. Sempre achei que essas duas pastas, ou as suas atividades, devessem ser comandadas por uma única pessoa, uma espécie de subsecretário de Segurança Pública, um subsecretário de Administração Penitenciária ou um secretário, digamos, de Defesa Social, que incluiria também,
[1] Fernando Salla é doutor em Sociologia pela USP e Pesquisador-Sênior do NEV (Núcleo de Estudos da Violência). Ver créditos de Paula Miraglia na p. 7 . 
quem sabe, um secretário de Justiça. Afinal, são três áreas afins, que não deviam ter comandos separados. Isso dificulta muito. Há quem diga: "mas tem o governador". Claro, o governador comanda todos os secretários, mas ele não tem tempo, nemé a sua atribuição, para cuidar das coisas que acontecem no dia-a-dia.

O sr. sentiu diferença, nas duas administrações em que trabalhou, em relação à obtenção de recursos necessários para aumentar o número de vagas, de prisões, de funcionários?

Não. Na verdade, participei muito pouco da gestão Mário Covas. Entrei no final de 1999, o governador Covas faleceu no começo de 2001 e, em 2000 , ele tinha enfrentado graves problemas de saúde. Então, trabalhei mesmo na administração Geraldo Alckmin.

Quanto à dificuldade de conseguir recursos, o principal entrave foi a Lei de Responsabilidade Fiscal, a Lei Camata, que limita os gastos com funcionários. O governo de São Paulo estava legalmente impedido de nomear novos funcionários, chegou a ficar quase seis meses sem a possibilidade de nomeação de novos funcionários. Isso com um fluxo de 800 prisioneiros, a mais, por mês, em todo o estado. Não foi por falta de vontade política do Governador, mas sim por um obstáculo legal incontornável.

Com relação à liberação dos recursos para novas obras, o que pôde ser feito foi feito, inclusive considerandoesse assunto como prioritário. Mas o grande problemaéa dificuldade em construir novas instalações prisionais:procura-se um lugare todo seu entorno sevolta contra.Isso provoca o atraso das obras, o que traz muitos outros problemas. Portanto, exceto com relação aos funcionários, não tenho queixas sobre isso.

Durante esse tempo a comunidade mudou sua forma de encarar esse problema. Isso provocou algum impacto na administração pública; refletiu nas politicas de governo?

Procurei debater o tema da "Execução da privação da liberdade" em todos os lugares onde isso fosse possível, debater a necessidade da atualização da legislação penal, a atuação do Ministério Público e do Judiciário nessa área, a participação da polícia na continuidade das investigações das atividades das pessoas já presas. Gostaria de que os resultados desses debates tivessem sido um pouco mais eficientes do que foram; mas na verdade o impacto não aconteceu. Basta verque, depois da avaliação da crise gravíssima de maio de 2006 , não se discutiu quase nada. Nesse período houve uma grande discussão na imprensa, mas bastou que as rebeliões e os ataques cessassem, para o debate desaparecer.

Os acontecimentos de 2006 tiveram alguma vinculação com uma série de medidas que o sr. foi adotando em relação ao funcionamento do pró- 
prio sistema. Por exemplo, durante o ano de 2000 , vários diretores foram afastados, além disso, o senhor propôs a descentralização da Coordenadoria dos Estabelecimentos Penitenciários (Coespe). Resta saber, então, se a megarrebelião teve motivações exclusivamente relacionadas à dinâmica da massa carcerária ou se teve alguma relação com essas medidas que o sr. adotou, e que de certa forma podem indicar uma certa conivência dos funcionários com essa movimentação dos presos.

Acredito que a origem da megarrebelião de 18 de fevereiro de 2001, como também dessa grande crise de maio de 2006, está ligada ao PCC. Não há dúvida alguma com relação a isso. Em 2001, a rebelião aconteceu logo depois da transferência dos líderes dessa organização criminosa para presídios mais rigorosos; e em 2006 foi a mesma coisa. É claro que por trás disso existem os problemas com os servidores públicos coniventes, que procuravam dar regalias para determinadas lideranças criminosas em troca de uma paz aparente. Eles foram sendo afastados pouco a pouco. Isso pode ter tido alguma influência, mas o ponto que determinou mesmo essas duas crises foi a movimentação da liderança do PCC.

Além disso, durante a minha gestão não se fez nenhuma espécie de concessão ao PCC. Pode ter havido uma ou outra concessão na ponta, mas como atuação de Governo, uma concessão ao "partido", à organização criminosa como uma forma de manter a paz, isso nunca aconteceu.Éclaro quequem procura cumprir a lei sem fazer concessões acaba provocando descontentamento e, conseqüentemente, rebeliões.

Nesse sentido, em 2006, uma das coisas que se comentava era a dificuldade da Secretaria de Administração Previdenciária contar como apoio da Secretaria de a Segurança Pública, em termos de inteligência policial para alcançar as ramificações do PCC dentro e fora das unidades prisionais. Isto foi constante nesse período: a falta de empenho dessa área?

De fato, o empenho foi muito pequeno, porque o Deic, órgão incumbido de combate o crime organizado, praticamente não mantinha contato com a Secretaria de Administração Penitenciária. Por essa razão, criei um Departamento de Inteligência dentro da própria SAP, para conseguir um pouco mais de eficiência, mas não havia absolutamente recurso algum. Um bom serviço de inteligência precisa de pessoas com formação policial, e não existiam funcionários com formação policial dentro da SAP, a não ser aqueles que fui buscar, já aposentados. Minha intenção era ter um departamento de inteligência dentro da SAP minimamente equipado, contando com policiais e equipamentos da ativa. Isso foi solicitado inúmeras vezes, mas infelizmente não se conseguiu, o que, em grande parte, foi o problema gerador dessa crise toda. 
Por que o sr. acha que não havia esse diálogo com o Deic, já que os interesses, nesse caso, podem ser vistos como interesses convergentes?

Por várias razões. Primeiro porque o pessoal do Deic e da Segurança Pública sempre teve uma visão de que o criminoso depois de recolhido à prisão, a uma penitenciária, é como se fosse uma coisa arquivada. É um problema a menos para eles. A visão policial sempre foi voltada para os que estão soltos, esquecendo que os presos continuam vivos, comunicando-se com os comparsas que estão do lado de fora da prisão, e chegando, até, a comandar o crime organizado de dentro das grades. Diria, então, que a visão dos responsáveis pela Segurança Pública foi equivocada.

De uma forma ou de outra, depois da megarrebelião de 2001, a impressão que se temé de que sua posição saiu fortalecida, pois o sr. conseguiu, por exemplo, descentralizar a Coespe [Coordenadoria dos Estabelecimentos Penitenciários do Estado de São Paulo], criando coordenadorias regionais, afastando diretores, pedindo, inclusive, o afastamento do próprio Coordenador. Ehouve uma série de esforços para criar uma administração com mais protocolos, com mais procedimentos previstos. Nesse sentido, a estrutura da SAPfoi suficiente para asseguraresses padrões de inovação que o sr. estava propondo?

Quando eu assumi a Secretaria havia uma única coordenadoria, que era a Coespe, e a sua divisão aconteceu antes da rebelião de 2001, com todo o apoio do governador Mário Covas - embora não tenha sido nada fácil descentralizar a Coespe em cinco coordenadorias territoriais. Com o governador Geraldo Alckmin, também houve apoio do governo nessa área, exceto em relação ao que dependia da Secretaria da Segurança Pública. Embora o governador muitas vezes tivesse determinado, ou ao menos tentado, que fizéssemos um trabalho mais harmônico, houve dificuldades de ordem pessoal.

No que dizia respeito aos funcionários, a questão era conclusiva: a população carcerária cresceu muito mais rápido do que o número de funcionários. Havia àquela altura, por exemplo, no Centro de Detenção Provisória (CDP) do Belém mais de 2 mil presos, três vezes a capacidade do presídio, e o plantão era feito, no máximo, por quinze policiais. Aliás, não sei como ainda não aconteceu uma tragédia nesses locais, porque o limite máximo que a segurança aconselha nos CDPs são 1.100 presos, mais do que isso é uma enorme irresponsabilidade. O ideal seria funcionar com 768 presos, mas até 1.100 seria administrável, sem afetar a parte de segurança. Por isso, quando vejo hoje alguns locais com 768 vagas e 2.200 presos, só posso concluir que o limite da responsabilidade já foi ultrapassado, isso representa um enorme perigo para a sociedade. 
Eu gostaria de que o sr. falasse um pouco mais sobre isso, de que maneira a superlotação pode ser perigosa.

O perigo é mais do que evidente porque, se houver uma rebelião num local que tem três vezes mais presos do que a sua capacidade, pode acontecer de todas as instalações serem danificadas e tornar-se um local totalmente inabitável. Se isso vier a acontecer, por exemplo, em dois CDPs, serão cerca de 4.400 presos que não terão onde ficar, porque nãoé possível enviá-los para as outras unidades, que já estão superlotadas. É grande drama, portanto, saber aonde eles serão levados. Segundo problema: numa rebelião desse porte, a possibilidade de os presos fugirem é grande. Imagine 2.200 presos em fuga,é um desastre total para a segurança da sociedade, especialmente, da comunidade próxima dessas unidades regionais. Então é preciso encontrar um mecanismo ou que abra mais vagas rapidamente, ou que permita a soltura dos presos menos perigosos. Esse fluxo de entrada, o equilíbrio entre a entrada e a saída dos presos, é algo que sempre tentei encontrar, buscando agilizar, junto ao Judiciário, o andamento dos processos de Execução. Era um esforço para tentar encontrar vagas para o novo contingente de presos que aumentava a cada mês, seja por meio de alvarás de soltura, fosse pela amplição dos mecanismos das Centrais de Penas Alternativas, fosse construindo novas unidades prisionais.

\section{OJudiciário foi ou é cooperativo com os dramas do Executivo?}

Não foi, não sei se é hoje, comigo não foi. Nem diria que isso acontecesse por falta de vontade dos juízes, mas principalmente por falta de compreensão dos juízes em relação à dimensão do problema, por falta de engajamento nesse problema. Sem idéia do drama que vive o administrador público, o juiz aplica o Direito a cada caso individualmente, sem se preocupar em ter uma visão de conjunto. Mas especialmente na Corregedoria Geral da Justiça, na gestão do corregedor Gilberto Freitas de Passos, houve uma preocupação em tentar compreender os problemas pelos quais a SAP passava e ajudar na sua solução. Mas realmente esse trabalho conjunto, entre dois poderes de Estado, não houve.

Como sensibilizar o Judiciário para essa dimensão do Executivo que ultrapassa o momento do julgamento de um crime, como aproximar esses poderes?

Houve três encontros de juízes, promotores, diretores de penitenciárias, afinados com a Administração Penitenciária, a Procuradoria e a Defensoria Pública. Foram encontros muito bons, mas eu diria que há um equívoco na Lei de Execução Penal.Acho que a forma pela qual a Lei de Execução Penal está colocando a questão da aplicação da pena de privação da liberdade não funciona. Defendo que a questão de progressão de regime de concessão de remição, concessão de saída temporária, e 
várias outras coisas não deveriam ser atribuição do Poder Judiciário. Isso deveria ser atribuição do Poder Executivo. E caberia ao Ministério Público e ao Poder Judiciário a tarefa - que não está sendo feita hoje de fiscalizar e exigir o cumprimento da lei.Seo Judiciário e o Ministério Público estivessem cumprindo esse papel, certamente essa situação, como a do presídio de Belém, com mais de 2 mil presos, não estaria acontecendo. Então, em vez de cuidarem dessa questão, que a meu a ver é muito mais importante, os juízes preocupam-se e gastam toda sua energia examinando a conta de liquidação de cada preso individualmente, quando a Administração Penitenciária faz isso hoje com muita eficiência, com banco de dados informatizado e muito mais.

Osr. acha que o advento da Defensoria Pública em São Paulo muda um pouco esse quadro?

Tenho sérias dúvidas. Acredito que essa parte de administração penitenciária deveria se voltar para a Lei de Execução Penal. Deveria haver uma lei federal traçando algumas linhas principais desse assunto e o restante deveria ficar a cargo de cada estado legislar. A constituição permite hoje que o estado-membro faça sua legislação de administração penitenciária, legisle supletivamente à União, porque não dá para comparar a realidade de São Paulo com a realidade do Acre, a realidade do Amazonas com a do Rio Grande do Sul. Cada estado deveria ter o poder de legislar sobre isso. E há exemplos de alguns estados onde o Poder Judiciário funciona muito bem na área de execução penal. Em São Paulo, por exemplo, funciona muito mal, porque há excesso de trabalho e poucos funcionários, juízes etc.Algo que também seria preciso repensaréa questão do sistema progressivo de cumprimento da pena. Não diria que deveria ser extinta, mas a verdade é que do jeito que está hoje, embora a intenção do legislador fosse a melhor possível, não está funcionando.

Por que o sr. acha que não está funcionando?

O regime aberto instituído em 1984 nunca existiu em lugar nenhum. Não virou realidade, como uma daquelas leis que não pegaram, como se diz. O regime semi-aberto também não funciona, porque o preso que vai para esse regime, faltando muito tempo para terminar de cumprir a pena, muitas vezes não consegue suportar a situação de semiliberdade e busca fugir. Ele não consegue seguir às cegas o regime semi-aberto, e o regime fechado é essa tragédia que nós estamos vendo, pois deveria ser cumprido em uma cela individual, mas existem 20,30 presos numa cela só. Portanto acho que tudo isso precisaria ser repensado.

O sr. acha que é fundamental o debate sobre o aperfeiçoamento do sistema de justiça criminal, como a ampla revisão da estrutura legislativa? 
Acho. Penso que a Lei de Execução Penal pecou em muitos pontos: por exemplo, quando se criou a figura da cadeia pública como um lugarem que os acusados devem ficar aguardando julgamento e depois da sentença serem transferidos para uma penitenciária para cumprir suas penas. Acho isso um equívoco diante da nossa realidade do país. Imaginemos uma pequena cidade, com aquela do Pará que ficou famosa por ter deixado uma adolescente ser colocada numa cela masculina. Há centenas de situações desse tipo no país, pequenas cidades com uma diminuta cadeia pública. Cidades cujas cadeias públicas estão superlotadas, como a de Contagem (MG), onde há 50 presos num lugar previsto para 6 vagas. Isso é um absurdo total. Mas um dia esses cinqüenta presos serão julgados e irão provavelmente de Contagem para Belo Horizonte. Aqui, no Estado de São Paulo, em uma pequena cadeia pública, imaginemos, em Eldorado Paulista, que mantém de cinco a quinze presos, a pessoa é julgada e pode ter que cumprir a pena em Presidente Venceslau. Não há sentido nisso. Acho que é muito mais importante manter a pessoa presa perto da sua família, seja esperando julgamento ou cumprindo pena. É preferível isso, ainda que se misturem os provisórios com os já condenados, a manter esse aparente princípio científico de que os condenados não podem ficar juntos com os que não foram julgados ainda.

Mais importante do que isso ainda seria criare manter as pequenas cadeias públicas que o Brasil sempre teve, procurando melhorar a administração, procurando melhorar o espaço e não exigir que as pessoas condenadas sejam transferidas para 400,500 quilômetros de distância de sua família. Mas para isso seria necessário fazer uma revisão quase total da Lei de Execução Penal.

Qual a sua opinião em relação às mudanças de legislação, que muitas vezes acabam aparecendo como uma grande solução? Como conjugar a necessidade de uma revisão das leis, como o sr. propõe, com os apelos a favor de uma legislação mais dura?

Nunca acreditei que endurecer a legislação penal fosse uma forma de atacar os problemas de administração pública. Quando falo que há necessidade de mudança na Lei de Execução Penal, muita gente alega ela nunca foi aplicada de fato, por isso não há como saber se ela funciona ou não. De fato, ela nunca foi inteiramente aplicada, mas não acho que isso ocorra porque no Brasil há uma vocação para descumprir a lei, mas sim porque aquilo que se exige para o cumprimento da lei é materialmente inexeqüível. Não há recurso para implementar a lei com todas as previsões que ela tem. Dou um exemplo: "toda pena de reclusão em regime fechado vai ser cumprida em cela individual". Se isso fosse possível, seria realmente uma coisa muito boa. Em São Paulo, foi inaugurada em 2002 a prisão de segurança máxima de 
Presidente Bernardes, onde se aplica o RDD (Regime Disciplinar Diferenciado). Uma única cela individual naquele presídio custou na época 45 mil reais. Uma única vaga. Um apartamento médio, de $50 \mathrm{~m}^{2}$, custava na época mais ou menos 55 mil reais. Ou seja, uma única vaga tem um custo altíssimo, que o país não suporta. Portanto é uma lei mas uma lei criada num país que não tem condições financeiras de cumpri-la, esseé o grande problema.

Seria um equívoco dizer que os governos estaduais, com uma ou outra exceção talvez, tenham pouca disposição para enfrentar os problemas relacionados à área da punição, ao sistema penitenciário? Em termos de recursos, os estados estão sempre de "pires na mão" com relação ao governo federal, estão sempre reclamando do dinheiro, que falta dinheiro; até os estados mais ricos estão com suas prisões completamente deterioradas, arruinadas. Como o sr. avalia essa situação?

Penso a esse respeito que a Lei Complementar que criou o Fundo Penitenciário Nacional não deveria existir. Porque, ao se regulamentar esse fundo com base na arrecadação da Loteria Federal (3\%), criou-seo pretexto para que os governadores, que têm de buscar os recursos no Governo Federal, se eximam de sua responsabilidade: "Eu não construo penitenciárias no meu estado porque o Governo Federal não libera os recursos do Fundo Penitenciário Nacional". Tornou-se uma desculpa para os governadores não priorizarem os investimentos nessa área. Era melhor que não existisseesse Fundo, porque eleé totalmente insuficiente para atender as necessidades do país. Ou então, se o Fundo continuar existindo, não deveria ser repassado aos Estados para fins de construção e sim para elaborar uma política nacional de administração penitenciária, de execução penal, ou então criar uma instituição federal incumbida de fiscalizar todos os estabelecimentos do país, incluindo agora a manutenção das penitenciárias federais. Porque da forma como está é muito ruim: os governadores reclamam que não têm recursos porque a União não libera. E a União, por suavez, diz "eu não libero porque o que se arrecada é muito pouco". Enfim, nem um nem outro acabam investindo.

Por outro lado o sr. vê algum obstáculo político entre a relação do Depen (Departamento Penitenciário Nacional) e os Estados, no sentido de implantação de uma política nacional, ou de algumas diretrizes nacionais, levando em conta o segundo mandato de uma administração do Partido dos Trabalhadores? Nos Estados em que há governos de outros partidos haveria mais dificuldade de engajamento politico nesse projeto, por causa de um apoio menos consistente do Governo Federal?

Não, nesse aspecto não vejo problema algum. $\mathrm{O}$ único problema que já cheguei a presenciar no passado, e que também vi acontecendo na 
mudança de um governo para outro, foi a dificuldade de conseguir a liberação dos recursos porque o Estado de São Paulo era de um governo de oposição ao Governo Federal. Tínhamos facilidade em liberar os recursos na época em que o PSDB dirigia o país, o que não aconteceu quando o PT assumiu o governo federal. Então nesse ponto deveria haver critérios mais objetivos de distribuição dos recursos federais e não critérios partidários como acontece hoje. E quanto à implementação da política de execução penal, também acho que não há nenhuma resistência, porque os responsáveis por essa política, nos estados, não têm esse viés partidário. Normalmente são técnicos que dirigem a Secretaria de Justiça, de Administração Penitenciária, e por isso poderia haver um entrosamento bom como Depen se ele fosse um órgão que estivesse realmente preocupado em implementar essa política no país inteiro. Não era eficiente — vamos deixar isso bem claro-, não era eficiente no passado, e não é eficiente hoje.

Além disso, retomando a questão do repasse dos recursos do governo federal para os estados, há uma coisa importante a ser dita. Em determinado estado, o Estado de Minas Gerais por exemplo, cuja situação carcerária me parece ser bastante complicada, caberia ao governador e à Assembléia Legislativa decidir: "nós vamos manter essa situação desumana que acontece hoje, enfrentando todo o desgaste político que isso traz, mas liberando recursos para outras áreas; ou vamos sacrificar um pouco as outras áreas para dar prioridade ao problema penitenciário?". Então a Lei de Execução Penal dependeria das decisões de cada Estado, seja no caso de não querer investir, seja no caso de querer mudar a situação. Por exemplo, a opção pelo sistema de progressão de pena com menor lastro de tempo: isso traz desgaste político? Traz, mas é uma opção que cada Estado faria. Não haverá investimento em construção de penitenciárias, mas a sua superlotação, situação desumana, será combatida. Como? Por meio de uma Lei de Execução Estadual que permitirá, por exemplo, que uma pena de oito anos de reclusão possa ser substituída por penas alternativas. Por outro lado, em outro Estado essa diretriz não seria aceita: "não, isso não é razoável, alguém que é condenado a oito anos precisa cumprir uma boa parte em regime fechado"; a conseqüência dessa posição é uma só: necessidade de investir mais na construção de unidades prisionais. Isso não acontece hoje porque o Estado não tem influência nenhuma na legislação que concerne ao tempo que a pessoa permanece presa. Isso, na minha opinião, deveria mudar. As principais diretrizes da Lei de Execução Penal seriam dadas por Lei Federal e o restante ficaria por conta de cada Estado.

Eu queria que o sr. falasse sobre o crime organizado. No Brasil ocorre uma experiência singular, talvez única no mundo: alguns grupos orga- 
nizados formam-se nas prisões, no Rio de Janeiro, aqui em São Paulo e agora também em outros estados. Como o sr. vê essa questão, do fortalecimento do crime organizado dentro das prisões? A que se deve isso?

Tenho a impressão de que essa questão foi muito mais grave em São Paulo do que em qualquer outro lugar. E o pior é que esse mau exemplo de São Paulo acabou se alastrando para outros Estados. Digo isso porque no Rio de Janeiro, por exemplo, as organizações criminosas que existem dentro dos presídios são aquelas organizações que já existiam fora. São os membros do Comando Vermelho que acabaram sendo presos equelevaram a organização para dentro das prisões. Mas em São Paulo aconteceu uma coisa inédita: algo que não existia na rua foi formado dentro das prisões. Creio que não tenha havido outra motivação para isso a não ser a falta de controle do Estado sobre seus presos. Mas por que há falta de controle? Porque havia muita gente presa num único lugar, sem que houvesse agentes ou servidores públicos investigando a movimentação dos detentos. O modelo que se criou em São Paulo, há 40,50 anos, sempre foi este: de penitenciárias grandes, como as de Avaré, Araraquara, Presidente Venceslau, com $500,800,1.000$ presos, poucos funcionários, que não têm a menor condição de observar a atuação de cada preso. Então, daquele grupo enorme de detentos que ficam conversando o dia inteiro, formar uma organização criminosa foi só um passo.

Além dessesfatores, qualé o papel da corrupção, da autoridade em geral, da conivência dos funcionários neste quadro?

Esse é um grande problema, mas há um outro além da corrupção. Em qualquer agrupamento humano, nós sabemos que existem pessoas quelideram as demais. Por isso sempre houve entre diretores e funcionários do sistema penitenciário uma mentalidade segundo a qual é mais fácil, e talvez até mais eficiente, manter a paz dentro de uma unidade prisional se a Direção estiver em sintonia com os líderes dos presos. Nesse caso, nem entraria o elemento corrupção, mas simples comodismo mesmo de funcionários e diretores: "Eu não posso deixar que aconteça uma rebelião na unidade que eu dirijo, então eu tenho que ficar mais ou menos em paz com aqueles que lideram os demais presos". É isso que leva à formação dessas facções criminosas. Porque esses líderes não estão preocupados, como apregoam falsamente por aí, com o bem-estar dos presos, isso seria ótimo, mas eles estão preocupados em ganhar dinheiro; esseé o problema.

O Regime Disciplinar Diferenciado (RDD) pode exercer um papel importante no controle dessas lideranças...

$\mathrm{Sim}$, mas isso teria que funcionar. O ideal é que houvesse um RDD nacional com, digamos, uns quinze presídios de segurança máxima 
espalhados em todo o território nacional, para onde pudessem ser encaminhados os líderes das facções criminosas. E se houvesse possibilidade legal de se transferirem os líderes mais perigosos de uma penitenciária para outra, diria que esse problema, se não acabasse, diminuiria bastante. Porque não é difícil detectar dentro de uma unidade prisional aqueles líderes negativos. Detectados, faz-se a transferência deles. O ideal mesmo seria tirar o preso da sua base de atuação: aquele que tem uma base de atuação no Rio de Janeiro vai para o Rio Grande do Norte, por exemplo, onde passaria dois, três meses; começou a formar uma nova liderança, vai para o Rio Grande do Sul. Isso dificultaria muito a vida do criminoso.

A impressão que se tem é de que há uma rede muito grande, uma ligação que extrapola um pouco a realidade interna no presídio, e entre presídios. Mesmo com o RDD, há notícias de festas promovidas neste ou naquele presídio. Querdizer, a impressão que se teméque o crime organizado tem uma complexidade muito maior que envolve outras redes, outras formas de comunicação, que há um poder dentro dos presídios que é maior do que esse construído por uma liderança apenas. Em suma, de que maneira o crime organizado está disseminado dentro e fora do presídio e como essas coisas se articulam? Há como enfrentá-las efetivamente?

Não vejo outra maneira de enfrentar essa situação a não ser por meio de investigação e serviço de inteligência que só a polícia é capaz de fazer. Uma ligação entre um preso, por exemplo, da Penitenciária de Presidente Venceslau com alguém da Baixada Santista não é algo tão difícil de ser investigado; mas é trabalhoso. É preciso ter uma equipe grande de policiais - era isso que eu pretendia instalar lá na Secretaria ou em conjunto com a Segurança Pública - delegados de polícia, investigadores, para que as investigações tenham sucesso. Deve-se, por exemplo, saber quantos visitantes um preso recebe, quem são essas pessoas, que tipo de vida elas levam, têm um bom padrão de vida sem ter fonte lícita de recursos? Isso é motivo para investigar: pode ser uma quadrilha que esteja se formando. Então, do universo de $150 \mathrm{mil}$ presos, imagino que mais ou menos 1.500 estejam efetivamente envolvidos nessas atividades. Todos eles devem ser investigados, dia e noite, todos os 1.500 , e todos os que se relacionam com eles. Claro que esse é um trabalho de longo prazo, mas se essas pessoas forem investigadas, indiciadas em inquéritos, denunciadas, condenadas e cumprirem pena, um dia essas organizações vão deixar de existir, porque todos estarão presos.

\section{Eporque isso não acontece?}

Não acontece porque dá trabalho. Não diria queé falta de vontade, pois é preciso ter gente designada para fazer isso. Não são dez pessoas, cem 
pessoas, precisaria ter muita gente da polícia designada para fazer isso. E diante de tantas outras prioridades que existem, talvez não tenha sido possível fazer isso ainda.

Na sua avaliação, o sr. acha que o PCC está controlado, devidamente desarticulado? Qual é a sua avaliação sobre ele hoje, e também sobre a SAP?

Não tenho informação suficiente para responder a essa pergunta, mas com certeza as investigações sobre as atividades dos líderes melhoraram.É a notícia que tenho. Seus membros estão sendo acompanhados mais de perto pelo serviço da inteligência da polícia. Há algumas coisas das quais desconfio, mas sobre as quais não tenho condições de afirmar concretamente. Em todo caso, posso emitir minha impressão. O RDD de Presidente Bernardes, por exemplo, quando eu saí, estava com quase todas as vagas ocupadas. Há pouco tempo, me disseram que há 30 presos para 170 vagas. Será que o comportamento nos outros presídios melhorou tanto a ponto de não ter sido mais preciso mandar ninguém para lá, ou existe, quem sabe, uma espécie de acordo de que ninguém vai mais para lá se a paz for mantida?

Voltando à crise de maio de 2006, sobre a qual o sr. falou brevemente, acompanhamos os fatos pela imprensa, e o que chamou a nossa atenção foram as múltiplas versões que apareceram sobre o episódio. E todas, aparentemente, bem informadas, histórias muito ricas, mas com versões muito diferentes. Não sei se o sr. poderia contar a sua versão.

Claro. A transferência dos presos em 2001 e a transferência em maio de 2006 foram os dois fatores que desencadearam as duas grandes rebeliões. Mas no caso de 2006, há um componente novo queé possível se analisar objetivamente. Em 2003, boa parte de 2004 e quase até a metade de 2005, quase não houve rebeliões mais significativas no Estado de São Paulo. Aliás, em 2003 não houve rebelião de espécie alguma: nem a menos grave, nem a mais grave. Não houve nada. Em 2004 houve algumas rebeliões, mas pouco graves, duas inclusive foram em penitenciárias femininas. Muito bem, porque então, em meados de 2005, começaram sistematicamente a acontecer rebeliões, com características de destruição, sem reivindicação nenhuma. Houve alguma mudança importante em 2005 que deixasse os presos descontentes, a ponto de provocar todo esse movimento? Eu diria que não. O secretário era o mesmo de 1999; a grande maioria dos diretores que deveriam ser substituídos já tinham sido substituídos. Portanto, os homens que dirigiam os presídios em 2005 eram os mesmos de 2003 e 2004 praticamente. A superlotação em 2005 não se agravou em relação aos anos anteriores, embora tenha havido, sim, um pequeno aumento do número de presos em cada unidade prisional; os 
funcionários eram rigorosamente os mesmos, portanto, o tratamento que o preso recebia em 2003 e 2004 era exatamente igual ao de 2005 . Então, por que as rebeliões começaram a acontecer? Começaram porque o PCC, por alguma razão, decidiu isso. E as informações que nos chegavam à Secretaria, vinham desta forma: "vai haver eleição no ano que vem". Muitos acham que estou tentando dar alguma justificativa político-eleitoral, mas são dados rigorosamente objetivos. Como eu disse, o tratamento dos presos não mudou em 2005, os funcionários eram os mesmos etc. Muito bem, então, naquele ano de 2005, especialmente de julho em diante, nós começamos a receber informações deste teor: "o PCC determinou a realização de uma rebelião em tal penitenciária equeera para quebrar tudo o que tinha lá". Qual era a reivindicação? Não tinha reivindicação - "vão quebrar, porque vão quebrar". Isso foi se repetindo e a cada mensagem que o PCC passava aos seus companheiros, li várias dessas mensagens, diziam que queriam Lula como presidente da República, Marta Suplicy, governadora de São Paulo, um advogado da cidade de Marília como deputado estadual e, ainda, "não queremos Alckmin como presidente da República". Não estou dizendo que o PT tinha algo a ver com isso. Não tinha absolutamente nada a ver com isso, mas os presos acharam que tinham de fazer rebeliões e escolheram essa bandeira para justificá-las. Por quê? Não sei dizer. Alguns conjecturaram que era por causa do governador Alckmin, que criou o RDD em São Paulo, mas não foi ele, na verdade fui eu, ou melhor, foi o governo dele. Alguns líderes do PCC imaginavam que, caso o Geraldo Alckmin se elegesse presidente da República, ele construiria várias penitenciárias federais nesse sistema de RDD. O raciocínio deles era este: "todos nós vamos ser transferidos para muito longe; se isso acontecer, a nossa carreira criminosa terá chegado ao fim, portanto, vamos fazer de tudo para que esse homem não seja eleito". Não consigo enxergar um outro componente que tenha determinado as rebeliões além desse. Elas começaram a acontecer em 2005 e continuaram no começo de 2006 - numa quantidade e gravidade cada vez mais crescente. Havia notícias vindas de todos os cantos, de todas as penitenciárias, de que a megarrebelião de 2006 seria feita em agosto daquele ano, ou seja, nas vésperas da eleição de outubro, e nós, simplesmente nos antecipamos, tomamos providências para tentar evitar que as rebeliões continuassem acontecendo e que essa grande rebelião anunciada para agosto acontecesse. Ou seja, transferimos os presos no mês de maio e por vários equívocos operacionais, informações que vazaram, depoimentos de delegados de São Paulo em sessão secreta da CPI do tráfico de armas que foram vendidos para um advogado do PCC, tudo isso fez com que a operação vazasse e desencadeasse essa reação extremamente grave que todos nós presenciamos. Enfim, não consigo encontrar outra explicação a não ser essa que eu dei. 
Defato, os presos temem esse isolamento mais severo. Isso aconteceu no Rio de Janeiro também. Alguns atentados que aconteceram lá em 2002 teriam ocorrido por causa da transferência de lideranças para o presídio de Bangu 1. Osr.associa os acontecimentos de 2001 e os de 2006 em São Paulo às transferências? Efetivamente os presos temem isso, então? Temem. Não há dúvida nenhuma de que temem o isolamento, temem a imposição de regras mais duras do que as que normalmente encontram nas outras penitenciárias. Além disso, em 2006 , souberam que a Penitenciária Federal de Catanduvas passaria a funcionar entre junho e julho daquele ano, e só essa notícia, e de que haveria mais em outros Estados, foi suficiente para criar um sentimento de pânico entre os membros da liderança dessas facções, porque abriu-se concretamente a possibilidade de alguém de São Paulo ir cumprir pena no Paraná, ou cumprir pena no Rio Grande do Norte.

O que é um pouco incompatível com a idéia de que o governo Lula não investiria em regimes desse tipo, porque o governo Lula tem investido em segurança máxima...

Poisé, a visão dos líderes do PCC foi completamente equivocada. Imaginar que Geraldo Alckmin, eleito presidente, faria algo muito diferente daquilo que vinha sendo feito pelo atual governo do PT; que prejudicaria os presos, os líderes criminosos, foi um equívoco. Suponho que os líderes tenham sido induzidos por pessoas de má-fé, que nem presos eram, que viram nessa bandeira uma plataforma eleitoral e começaram a divulgar isso no meio dos presos.

Na época da rebelião de 2006 muitos postos policiais e soldados foram atacados. Foi dito na ocasião que o comando da polícia sabia de tudo que ia acontecer, mas não teria informado as bases, o que acabou gerando graves conseqüências. $O$ sr. acha possivel que isso tenha ocorrido? Era possivel informar a base da polícia, que assim poderia ter se preparado melhor, ou ninguém tinha como imaginar a dimensão dos ataques?

O grande problema começou, pelo que eu sei, na sexta-feira, 11 ou 12 de maio, e a decisão de se transferirem os presos tinha sido tomada na tarde da quarta-feira. A transferência começou na madrugada de quinta-feira e seestendeu até a noite do mesmo dia. Foram 760 presos transferidos para Presidente Venceslau, de diversos pontos do Estado. Todas as viaturas, dezenas delas, foram escoltadas pela polícia. Ou seja, ninguém tentou esconder nada da polícia. Tudo foi feito às claras, de maneira aberta e transparente. Ninguém imaginava que esses ataques contra as bases policiais fossem se dar com a dimensão e a gravidade que se deram. Participei da reunião em que o governador Cláudio Lembo decidiu a transferência. Defendi a transferência dos presos porque o número de rebeliões estava aumentando de tal maneira que 
alguma coisa deveria ser feita, que não era possível ficar de braços cruzados esperando a megarrebelião de agosto acontecer. Era uma forma de tentar evitá-la. Mas acrescentei na mesma reunião: "Agora, que tipo de conseqüência isso vai trazer aqui na rua eu não tenho a menor condição de avaliar". Estavam presentes à reunião o secretário adjunto de Segurança Pública, o subcomandante da Polícia Militar, dois policiais e um dos principais diretores do Deic. Todos fizeram a seguinte avaliação: vai haver reação, mas não deve ser uma reação diferente das que nós já enfrentamos, uma base policial atacada aqui, outra ali, nada que ultrapasse isso. E eu falei: "dentro do meu âmbito, eu acho que vamos ter rebeliões, mas nada que seja incontrolável. No limite do limite, se tudo der errado, podemos ter rebeliões em 70 unidades regionais". Tivemos em 74. "Podemos ter em 70 , que são as unidades nas quais o PCC tem influência, mas acho que, tirando esses líderes, os que vão permanecer não terão capacidade de decidir uma coisa dessas" - foi o que imaginamos. Portanto, ninguém escondeu nada de ninguém, a informação correu pela SAP, com certeza absoluta. Desde o mais alto coordenador até o último dos agentes penitenciários sabia o que estava sendo feito e a possibilidade de reação. Mas creio que ninguém imaginava que ia haver uma reação daquele tipo, isso é um fato.

A dimensão dos acontecimentos fora das prisões surpreendeu, a ousadia das ações alcançando até os transportes públicos...

Neste caso há uma avaliação que diz que os ataques ao transporte público não tiveram relação com o restante. Alguns aproveitaram aquele momento para aumentar o problema.

De qualquer forma, isso também é preocupante, porque vários jovens começaram a fazer atentados em nome do PCC.

E muitas desavenças pessoais foram resolvidas aproveitando aquele momento.

Na conta do...

...do PCC. Mas - é a pergunta que nos vem -, tendo sido capazes de desencadear um movimento daquela dimensão em maio de 2006 , se eles forem contrariados hoje, será que vão ficar quietos? Ou será que reagiriam com a mesma força? Não saberia responder a essa pergunta. Só contrariando-os para ver o que acontece.

Houve, depois, algumas manifestações diferentes, uma espécie de greve no Fórum, envio de algumas centenas de cartas para ONGs, estratégias muito mais pacíficas com intuito de apresentarem algumas queixas, opostas ao enfrentamento das autoridades.

Algo de que se tem quase certeza é que existe um grande comandante do PCC, queéo chefe de todos eles. Existe uma espécie de "Estado 
Maior". E o que esse grupo decidir, seja por uma razão ou outra, a massa segue. Obedece cegamente às ordens. Portanto, se hoje não está acontecendo nada, é porque eles decidiram que não compensa enfrentar o Estado daquela maneira que eles enfrentam.

De qualquer forma, acho que isso que aconteceu em São Paulo exerce um papel terrível em outros Estados. Porque vários grupos de presos começam a tomar conta das prisões, querendo enfrentar os agentes penitenciários, a polícia etc. Em contrapartida ao surgimento desses grupos, pensando na manutenção da ordem interna das prisões, cada vez mais se vem recorrendo ao pessoal militarizado, para manter a tal da ordem, algo que parece preocupante.

Há um outro dado sobre o qual é preciso falar, a respeito de uma decisão do Supremo Tribunal Federal, em 2004 ou no começo de 2005, que dizia que o artigo da Lei de Crimes Hediondos que impedia a progressão do regime era inconstitucional. Era uma decisão que beneficiaria centenas de criminosos, seria um motivo a mais, portanto, para ampliar a paz estabelecida em 2003 e 2004 . A perspectiva em 2005 , para os presos, era positiva, no entanto, a reação deles foi na direção contrária, porque havia outras motivações por trás que não o tratamento bom ou ruim ao preso.

Por que objetivamente as condições carcerárias mudaram tão pouco? E, por outro lado, osr. consegue observar alguma melhora?

Não, em relação ao espaço, com certeza, mudou para pior, porque hoje há o mesmo número de vagas e muito mais presos. Alguns dizem queo princípio de autoridade foi resgatado e que, por isso, a ordem vem sendo mantida. Se isso é verdade, trata-se de algo extraordinário, mas essa explicação não me convence, uma vez que as autoridades que tratam diretamente com os presos e que estão lá na ponta são rigorosamente as mesmas. Além disso, quando era secretário, jamais fiz algo para diminuir a autoridade dos diretores penitenciários. Pelo contrário, sempre os prestigiei, sobretudo os bons diretores, sempre lhes dei tudo de que precisavam, por isso tenho dúvidas quanto a essa alegação.

O sr. passou por alguma situação constrangedora como a que viveu o secretário José Carlos Dias, no periodo em que se deflagrou a politica de humanização dos presídios, durante o governo Montoro? Ele chegou a ser desafiado pelos funcionários, destratado de forma bastante agressiva, hostil. O sr. chegou a passar por alguma situação em os funcionários ou mesmo alguns diretores tenham discordado das suas orientações políticas?

Não. Existiram divergências, diretores que expunham suas discordâncias em reuniões, mas tudo era discutido num clima de educação e respeito. A única coisa em relação à qual senti certa oposição, até 
mesmo uma tentativa de ridicularização, foi a questão dos Centros de Ressocialização (CRs). Esses centros são unidades administradas de maneira totalmente diferente, começando pela concepção arquitetônica, totalmente diferente dos modelos tradicionais. Alguns mais céticos diziam: "não vai sobrar um preso num lugar desse, todos vão embora. Vai chegar o dia em que não vai ter nenhum preso cumprindo pena no CR". Era o que se dizia no começo. Mas o tempo se incumbiu de mostrar que nos CRs, apesar da pouquíssima estrutura de segurança, fugiam menos detentos do que nas unidades tradicionais de segurança máxima, e que aconteciam menos rebeliões ali do que nas demais. E nenhum homicídio! Nos 22 CRs, não aconteceu nenhum homicídio até hoje, creio. Na época em que fui secretário não houve. Aconteceu só uma rebelião, que não chegou a ser bem uma rebelião, mas um motim, em Presidente Prudente. Então, o tempo se incumbiu de mostrar que esse modelo era bom, sobretudo para aqueles que não acreditavam nele. Então, confrontos, hostilidade, contra minha autoridade não houve. O que contribuiu um pouco para que os funcionários "mais duros" confiassem na nossa política foi a questão do RDD, que era algo com que quase todos os diretores da linha-dura sonhavam, mas que nenhum secretário da chamada linha-dura havia tido a coragem de instituir.

A queda dos homicídios em São Paulo, que ainda é bastante controvertida, e os seus motivos são objeto de um debate bastante conturbado hoje. Um dos argumentos alegados é que eles caíram, entre outros fatores, em razão das altas taxas de encarceramento do Estado. Como o sr. vê a associação entre esses dois fenômenos?

Há um dado curioso de que poucos falam. Há dados estatísticos sobre homicídios só a partir de 1995, no governo Mário Covas. Antes disso, não havia registro. Desde então, de 1995 a 1999, o número de homicídios só subiu. Em 1999 quase estacionou e de 1999 a 2007 só caiu. Houve, então, a partir de 1999, uma mudança - embora isso não explique tudo - , um melhor gerenciamento dos recursos da segurança pública. A meu ver, isso é indiscutível. Essa mudança se deu na gestão do secretário Marco Vinício Petreluzzi, que assumiu a Secretaria em janeiro de 1999. Ele fez algumas coisas muito importantes de que se fala pouco atualmente. Ele compatibilizou a área de atuação da Polícia Civil com a da Polícia Militar, criou um sistema de informações em que todos os dados dos crimes eram conhecidos por toda a polícia quase imediatamente após o acontecimento. Com isso, foi possível direcionar recursos policiais para as áreas mais necessitadas, coisa que não acontecia. O Departamento de Homicídios passou a apurar a autoria de homicídios que antes não se apuravam, num número muito maior do que antes. Além disso, houve uma mudança que contou com 
a ajuda da SAP: a desativação gradativa das carceragens dos distritos policiais, o que fez com que investigadores e delegados fossem liberados da tarefa de cuidar de presos e passassem a investigar mais os crimes de autoria desconhecida. E isso se refletiu num dado importantíssimo: havia mais de 30 mil presos provisórios nas cadeias públicas e distritos policiais aguardando julgamento nessas suas carceragens. Quando eu saí da Secretaria, esse número tinha caído para algo em torno de 16, 17 mil. Nas carceragens das delegacias, havia muitas fugas mesmo, de 1995 a 1998 cerca de 20 mil detentos fugiram dessas carceragens. É um número fantasticamente alto. Imagine um autor de um homicídio ser preso, fugir pouco tempo depois e voltar para a sua comunidade, onde ele cometeu o crime. A sensação de impunidade é fantástica. Outros possíveis matadores se vêem incentivados a fazer isso.

Mas o aumento no número de encarceramentos devido à ampliação da identificação dos criminosos por causa do aperfeiçoamento da investigação policial, somado ao fato de os presos não conseguirem fugir mais, contribuir, não tenho dúvida disso, para a queda dos índices de homicídios. Houve outros fatores, como o desarmamento, mas a Lei do Desarmamento só foi promulgada em 2003 , e os índices em São Paulo vêm caindo desde 1999. Alguma coisa tem de ter acontecido no meio disso. A criação do Disque-Denúncia foi algo muitíssimo importante também. A bem da verdade, é preciso reconhecer, foi na gestão do Marco Petreluzzi que o número de denúncias anônimas disparou, o que levou à descoberta de vários criminosos. E também o trabalho das ONGs, das que atuam nos bairros, o fechamento de alguns bairros em algumas cidades, tudo isso somado deu esse resultado, que está entre, ao que parece, os melhores do mundo em termos de queda do número de homicídios. A meu ver, isso se deve a um melhor gerenciamento dos recursos públicos, incluindo a questão do encarceramento.

No Brasil, o número de presos mortos dentro das prisões é impressionante. Infelizmente, não há dados muito precisos sobre isso, mas todas as vezes que se conseguiu apurar, chegou-se a um preso morto para cada grupo de mil presos, o que é um dado astronômico comparado ao de qualquer outro país, onde o número de presos que morrem sob a tutela do Estado é muito pequeno. Lembro-me de que houve um aumento no número de homicídios dentro das prisões entre 1995 e o comecinho do ano 2000, e depois houve uma redução muito drástica. Osr. associava esse aumento de homicídios à consolidação do PCC, que buscava tirar a concorrência do caminho para consolidar o seu poder. Como o sr. vê isso hoje?

O número de homicídios em São Paulo, na minha gestão, acho que caiu bastante. Havia vários aspectos ligados aos crimes em presídios. 
Quando não havia certeza de "quem era inimigo de quem" dentro dos presídios e entre as facções, ocorria um maior número de mortes. No momento em que os grupos se tornaram mais facilmente identificáveis e foram separados, levados para penitenciárias diferentes, o número de embates entre eles diminuiu e, conseqüentemente, o número de homicídios também caiu. Mas há um outro dado também importante a ser mencionado e que diz respeito à separação que fizemos dos presos por tipos de crime. Os autores de crimes sexuais foram separados e levados para três ou quatro presídios diferentes. A partir daí, quase não houve mais homicídios de autores de crimes sexuais nas penitenciárias de São Paulo.Antes, eles ficavam junto aos outros presos, mas depois passaram a ser "protegidos", digamos, em penitenciárias específicas. Além disso, o fato de procurar separar de forma muito clara quem é de uma facção criminosa de quemé de outra trouxe bons resultados. Houve quem dissesse que isso era "reconhecer oficialmente a existência das facções"; e eu retrucava: "não é melhor reconhecer o que obviamente existe e, com esse reconhecimento, evitar a conseqüência mais grave de todas: os homicídios dentro das prisões?".

Todas essas medidas, enfim, melhoraram o funcionamento dos presídios. Ou seja, o trabalho de gerenciamento entre as áreas da Secretaria da Segurança Pública e da Secretaria da Administração Penitenciária foi um pouco mais afinado, o que contribuiu, a meu ver, de forma significativa para a queda no número de homicídios, embora, nem de longe, tenha sido a principal causa, mas que contribuiu, contribuiu.

E quanto à sua segurança pessoal, em algum momento o sr. se sentiu ameaçado ou enxergou a sua tarefa como uma tarefa de risco?

Não. Mas recebi inúmeras ameaças durante o tempo em que fiquei na secretaria. Não só contra mim, mas contra a minha família. Contudo, o que me deixou impressionado foram dois episódios ocorridos depois que eu saí. Em dezembro de 2006, e também em 2007, passou a circular uma informação de que o pessoal do PCC havia decidido que seis pessoas aqui no Estado de São Paulo deveriam ser assassinadas, e eu estava entre elas, eo pior, encabeçando a lista. Segundo apuraram, o que motivou essa decisão tinha sido a criação do RDD, que foi coisa minha. Portanto, eu seria o maior opressor do Estado de São Paulo e que, por isso, eu teria de ser eliminado. Foi uma coisa séria realmente, porque não só fui alertado por um promotor de justiça que era meu amigo e que tinha dados concretos sobre isso, mas também por um juiz de Direito, pela Delegacia Geral de Polícia, pelo Comando da PM, que chegou a colocar uma viatura na porta da minha casa. Mas felizmente não aconteceu nada. 
Recebido para publicação

em 27 de março de 2008.

NOVOS ESTUDOS

CEBRAP

80 , março 2008

pp. 21-41

\section{O sr. gostaria de falar mais alguma coisa?}

Eu esperava que, diante da gravidade da crise de 2006 , as autoridades, a sociedade inteira, estivessem analisando essas questões. Por exemplo, será que foram falhas individuais que provocaram essa crise, desentendimentos entre esta ou aquela autoridade, será que foi por isso que tudo isso aconteceu? Então, se buscarmos outros nomes que consigam se entender ao exercerem suas tarefas, ou que possam exercer com mais eficiência alguns cargos, o problema será resolvido? A meu ver, parece evidente que não e infelizmente não vi nenhuma discussão importante sobre as causas que levaram àquela crise. Isso é o que mais me preocupa, o fato de nada disso ter acontecido. 